\title{
Similarities and Differences between the Demonstratives in Kurdish and English language
}

\section{Shler Mohammed-Ali Najmaddin}

Computer Science Department , Darbandikhan Technical Institute, Sulaimani Polytechnic University, Darbandikhan, Kurdistan Region, Iraq .

Email: shlernajmaddin07@gmail.com

\section{Rezhna Maarwf Hwsein}

Kurdish Department, Faculty of Basic Education, University of Raparin ,Rania, Kurdistan Region, Iraq.

Email: Rezhna.maarwf@uor.edu.krd

\begin{abstract}
:
This study explores the English and Central Kurdish'demonstratives as deictic expressions by stating their morphological, syntactical and semantic properties. As a result, the similar and different linguistic properties of the demonstratives of the two languages are pointed out. The outcome of the study may provide more elucidation to linguistics in general. Additionally, it may give clearer vision to language pedagogy and translation.
\end{abstract}

Key word: English Demonstratives, Central Kurdish Demonstratives, Similar Linguistic property, different linguistic property

'Along this paper the word "Kurdish" has been used instead of Central Kurdish 


\section{Demonstratives in English:}

\section{1. Introduction:}

The term demonstratives is used in grammar and semantics to refer to a set of words and it roles as pointing to an entity in physical and linguistic context (Crystal, 2008, p. 135). They also indicate the spatial and temporal distance of the referent to the speaker and the hearer (Leech \& Svartvic, 2013, p. 521) (Maurizio Gotti).

Diessel states that it has been argued that demonstratives are determiners that do not take a complement and determiner with a nominal complement. Demonstratives correspond to verbs that are treated transitively in a determiner phrase or intransitively alone. In addition, both adnominal and pronominal demonstratives have been categorized as independent pronouns. There is also another argument which states that demonstratives are treated as "determiners which co-occur either with a noun or an empty head" (Diessel, 1999, P. 68). However, other grammarians assert on that pronominal and adnominal demonstratives belong to distinct classes despite the fact that they are phonologically and morphologically not different. "Adnominal this and that occur in a specific syntactic slot where they cannot be analyzed as pronouns, and there is no evidence that pronominal this and that function as determiners." Diessel, 1999, pp. 67-68; Roberts, 1999). The following examples are canonical uses of the English demonstratives:
a) This is beautiful
b) Those look particularly delicious.
c) These vehicles have four-wheel drive.
d) Stop that man! (Roberts, 1999, p. 92)

In (1 $\mathrm{a}$ and $\mathrm{b})$ this and those perform pronominal function, but in $(1 \mathrm{c}$ and $\mathrm{d})$ these and that function as adnominal.

\subsection{Primary Demonstratives}

There are four primary demonstratives in English: This, that, these, and those. They "encode a two way deictic distinction", "proximals" to refer to things that are relatively close to the speaker, on the other hand "distals" to point to a referent that is distant from the speaker. They also present contrast in number: singular and plural (Greenbaum, 2000, p. 136; Endley, 2010, p. 133). 


\begin{tabular}{|c|c|c|}
\hline & Singular & Plural \\
\hline Near & This & These \\
\hline Distant & That & Those \\
\hline
\end{tabular}

(Leech and Svartvic, 2013)

The use of the demonstratives for singular and plural:

(2)
a. This book - These books
b. That book - Those books (ibid)

The use of the demonstratives for near and not near things:

(3)
a. This paper is for the printer.
b. These reports are for the meeting.
c. That desk is Janet's.
d. Those are the sales reports (Reppen \& Gordon, 2012, p. 40).

This, that, these, and those are used before nouns to identify and describe people and things:
a. This photo is my favorite.
b. That little girl in the photo is my sister's daughter.
c. These charts are helpful.
d. Those papers are important.

The four primary demonstratives are used as pronouns to identify things:
a. This is the only copy machine.
b. That is the color printer.
c. These are the reports for the meeting. 
d. Those are my keys.

For introducing people only pronominal this and these are used:

A This is Claudia.

B Hi, Claudia! Nice to meet you.

A These are my co-workers, Mena and Liz.

B Hello. Nice to meet you.

(ibid)

The demonstrative this can be used to introduce new information in a narrative:

"I was walking along the street when this girl came up to me..." ( = "a girl I'm going to tell you about")

(Leech and Svartvik, 1994: 60)

Arts and McMahon state that English demonstrative pronouns are similar to definite article the since they indicate that the noun phrase they introduce are definite:

a. This / that politician

b. These / those politician

(Arts \& McMhon, 2006)

Nevertheless this can function as an indefinite determiner in informal speech. In this case, this corresponds approximately to $a$ or some.

(9) And there was this Frenchman who went to a cricket match.

(Alexander, 1988, p.323)

Likewise, these has the role of indefinite article when introducing new information. 
(10) There's all these horror stories about it happening, but I've never actually heard of it, actually happen to anybody.

(Greenbaum, 2000, p.136)

When the speaker/writer and hearer/reader share the same context, co-reference may occur. In such contexts, English demonstratives can be used as anaphoric expressions referring back to already mentioned antecedents and as cataphoric expressions referring to later parts of the discourse Ghubin, 2006, p. 24) cited from (Quirk et al. 1985, p. 382 ). (11 a \& b) are examples of the use of anaphoric and cataphoric demonstratives

a. Novelist Wright Morris says he always is working on a book "because this is the way I breathe". ( (Fan, 2013, p. 74)cited from (Botley \& McEnery, 2001))

b. 75 per cent of those who returned the questionnaire were in favor of the proposal.

(Leech

\& Svartvic, 2013)

Following some other scholars, Fan also regards it as a demonstrative reference (Fan, 2013, p. 74).

Nonetheless, that refers to things only (not people) when it is used as a relative antecedent. Those can be a referent to people.

(12) 75 per cent of those who returned the questionnaire were in favor of the proposal (Leech \& Svartvik, 2013).

According to the distributional properties of Quirk et al. (1958), in which determinatives are distinguished as three subclasses, the demonstratives fall in to the central determinatives. As explained in (13)

These three students (Arts \& McMhon, 2006) ${ }^{r}$

S/he replaces pronominal this and that and they replaces pronominal these and those when the referent is human or humanlike. Roberts assumes that in this case $s /$ he and they have the use of the demonstratives. (Roberts, 1999, p. 92)

\section{3. Other Demonstratives:}

Such probably have a demonstrative sense (like that or like this) as a pronoun or as a determiner relating to kinds.

'This example was made by the researcher who brought the words (these) which is central demonstrative and (thee) which is post demonstrative, according to the classification of the determinatives by Quirk et al. (1985: 253ff) 
a. Do I understand you to be saying that in such an accident uh a passenger would be thrown uh first of all forward and then backwards?

b. He is entitled to such payments, subject only to the limited category of cross-claims which the law permits to be raised as defences by way of set-off in such circumstances (Greenbaum, 2000, p. 137).

Demonstratives, both the singular and the plural pronouns can be used as pro-forms, as "reduced" NPs, to substitute for a noun phrase:

a. This chair is more comfortable than that. (= that chair or that one)

b. These apples are sweeter than those (= these apples or these ones)

(Fan, 2013, p. 74 \& (Ghubin, 2006, p. 23) cited from (Quirk et al, 1985: p. 372))

According to the findings of (Fan, 2013, p. 81) this is used more frequently than that to refer to antecedents.

Leech and svartvik state that that and those can be used as the word that is the antecedent referent of the relative pronoun as illustrated with the following sentences:

Richard took up a life similar to that (which) he had lived in San Francisco.

\section{r. Demonstratives in Kurdish Language:}

\subsection{Introduction:}

Demonstratives are described as those words that point to a definite entity, near or far, to identify the entity. "a word whose function is to isolate one of the things from the others, indicates the proximity and remoteness from the speaker and hearer, and is followed by a gesture or pointing at the referent." (rfîq şwanî, 2011: 45) 
According to the initial literature, demonstratives belong to two parts of speech; pronominal demonstratives and adjectival demonstrative. However, there is another classification, which puts the demonstratives as one group that can be used as demonstrative pronoun and demonstrative adjective. When they are treated as pronouns, semantically, they role as one type of noun and they can perform all the functions of noun in a sentence; as (subject or object, etc). They replace the noun and are instantly seen in one part in the sentence.

a. (em ktêbe mekre, ewe bkre.) don't buy this book. Buy that

b. (emane kên?) Who are these?

c. (ewane çî deken?) what do those do?

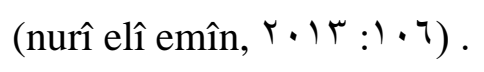

The term (ewe ) that in (18 a) in the second sentence replaces the noun book and demonstrates it as well. In ( b. and c.) the demonstratives these and those are used instead of a the name of a number of people.

In addition, demonstratives are used as demonstrative adjective. It is described as "an adjective that refers to something or someone" (nurî elî emîn,

2013:130). They are used with a noun and split into two parts. One of the parts precedes the noun and the other part follows the noun. Their form appears as the following: $\quad$ (em... e) (eu ... e) (em ... ane) (eu ... ane)

These two parts refer to nouns. When they refer to a noun, they define it (nerîman ebdulla xoşnaw, $r_{\cdot} \mid r_{\text {: }} \vee q_{-} \wedge \cdot$ ). As illustrated in (19)
a. em kure û eu kçe hatn. (this boy and that girl came)
b. em ktêbanew eu qelemane bêne. (bring these books and those pens)

In ( a. and b) the terms (em... e) $\mathrm{u}(\mathrm{eu} . . . \mathrm{e})(\mathrm{em} . .$. ane) (eu ... ane ) are demonstrative adjectives and refer to these nouns (kur, kç, ktêb, qelem)

It can be claimed that the demonstratives are pronouns just in the form of speaking and writing, however, they are demonstratives adjectives in their deep meanings and the entity they refer to is conceptualized. Thus, the entity is not coded, may be, since it is not needed or the situation is not proper to be stated (şêrko baban, 2008: 53- 54). 


\section{$\uparrow, \uparrow$. Primary Demonstratives in Kurdish Language:}

In general, there are four primary demonstratives in Kurdish Language.

(eme, ewe, emane, ewane)

Morphological Aspect of the Demonstratives:

The structure of the demonstratives:

$(\mathrm{em}+\mathrm{e})$ this $\longrightarrow(\mathrm{em}+\mathrm{an}) \longrightarrow$ (emane) these, infix (an) is used within (em, e).

$(\mathrm{eu}+\mathrm{e})$ that $\longrightarrow$ (ewe+an) $\longrightarrow$ (ewan) those, infix (an) is used within (eu, e ).

The demonstratives in Kurdish Language denote proximity and distance and plurality and singularity. They do not indicate the gender of their referents. Thus, they are different from the demonstratives in English language when they are singular. However, they are similar when they are plural.

(ewe, ewane) this and those are treated to refer to distant entities considering their lexical meaning, but they are used so frequently that it is used for both near and far items in speaking. Contrariwise, (eme, emane) this and these used to refer to near entities and is used for certain situations and less frequently used (şêrko baban, 2008: 66- 67).

The Kurdish demonstratives have other forms that are ( em, eu) - (eman, ewan). They are rarely used alone, but they cooccur with linking pronouns or with morphemes (ş/îş) (eurehmanî hacî marf, laAv: rs૫)

(20) Explains their use

emtan eum eutan eh myan emm (That of you) (that of theirs) (that of me) (this of you) (this of theirs) (this of me)

a. emyanm emtan ewanm ewanyan

b. (those of you) (those of theirs) (those of me) (these of you) (these of theirs)

emanm (these of me)

emyan legel xot bêne. (Bring this of theirs with yourself)

emîş emaņ emâş̧ ewânş

Those also these also that also this also 
emîş bhênn. (also (you) bring this )

The demonstrative (em) is used in structuring compound words such as (this year emsal, today emro, tonight emşew, this time emcar, this side, ember, that side euber).

zstanî emsal zor sard bû.

was cold very this year of winter.

emro deçîn bo seyran.

Picnic to we go today.

On the other hand, there is another assertion about this form of the demonstratives which states that ( em, eu) - (eman, ewan) are not demonstratives, but they are third person pronouns that indicate proximity and distance of the persons or things they substitute. As clarified in (22)

a. (eman başn ‘belam eman baş nîn.) these peaple are good, but those (they) are not good.

b.( em hat û roşt.) this came and that (he/she) went.

In the English translation of (22 a. \& b.) demonstratives replace the Kurdish third person pronouns as in their meanings the proximity and distance of the persons they refer to are indicated and there is not such personal pronouns in English to denote these Kurdish personal pronouns.

(şêrko baban, 2008: 50-51) (tara muhsîn qadr, 2004 :105)

There is also another form of demonstratives in Kurdish Language which is made as a result of squeezing the demonstratives. (bew, lew, bewe, lewe, bewane, lewane), (bem, lem, beme, leme, bemane, lemane), these are originally so (beem, leem, beeme, leeme, beemane, leemane), (beeu, leeu, beewe, leewe, beewane, leewane), (e/e) is omitted from the demonstratives (eurehmanî hacî marf, 1987 :252) since they are expressed easier. As explained in (23)

bem qeleme denûsm. (I write by this pen) bem (be em) (by this)

ktêbekan bew mindalane dênm. (I bring the books by those children) (by those) bewane (beewane) 
pareke lem we rbgre. (receive the money from this) (from this) lem (leem)

There are many other demonstratives in Kurdish Language that are used in other variants and dialects, but here Central Kurdish is mentioned such as: howe,howane. (that, those) (mesod mhemed, 19v $: \leqslant 1$ )

Demonstratives determine a name that is a determinative for another noun as;

a. xawenî em kêlgeye (kêlge) (owner of this field)

b. cutyarî em nawçeye (nawçe) (peasant of this area)

They also define a noun that the name is determined and occurs within the demonstrative adjective.

a. em baxewaney êwe (baxewan) (this gardener of you)

b. eu xanûey şasur (xanû) (that house of Shaswar)

When the demonstrative is used to define the whole term (the determiner and the referent), the determiner and the referent are changed to a compound word and then it occurs within the demonstrative adjective.

(26) mrîşkî sur (em mrîşke sure).

Red chicken (this red chicken)

Demonstrative adjective can also be used for nouns that are referent of quantifiers as explained in example (27)

a. em dû ktêbe bêne. (bring this two books)

b. eu dû pyawe hatn. (That two men came)

Co-reference is another use of the demonstratives. They are treated as cataphor to refer to a referent that occurs before the referent and as anaphor to refer to the later part of the discourse.

a. dalya herçende wêney zor deqîqî bekar hêna bo wesfkrdn û nasandnî xewnekanî bbelam ewe bû be yekêk le berbestî karekanî. 
b. (Even though Dalia used a very precise picture to describe and identify her dreams, that became one of the obstacles in her works)

b. euey ême mebestmane 'karekanî hukmete. (that we consider is the government's jobs) (mhemedî mehuy, 2001: 213 ) .

Moreover, the four primary demonstratives of Kurdish can refer to people when they are used as relative antecedents.

(ewaney ke hatn) those who came (euey ke hat) that who came.

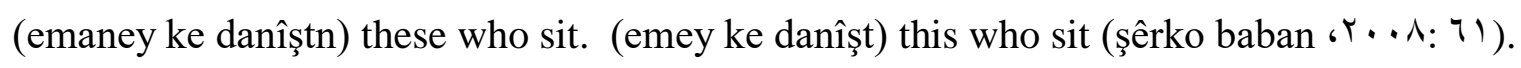

r. 1. Contrastive Analysis

The outcome of the information above about English and Kurdish demonstratives is pointing out the following similar and different points between the two languages.

\subsection{Similar points:}

1. Demonstratives exist in both Central Kurdish and English.

$r$. In both languages demonstratives indicate that the referent of the associated noun phrase is near or remote and show the grammatical category of number: singular or plural.

r. Despite the fact that there are some differences in the classification of the demonstratives in both Kurdish and English, grammarians in general, divide demonstratives into two groups; demonstrative pronoun and demonstrative adjective.

$\varepsilon$. They are used to point to an entity in a situation or a sentence.

•. Quantifiers that fall in to the central determiners in English, precede the noun and follow the demonstratives in both languages.

7. Demonstratives, both the singular and the plural pronouns can be used as pro-forms, as "reduced" NPs, to substitute for a noun phrase.

v. Both Kurdish and English demonstratives do not demonstrate gender of their referents.

^. Demonstratives have co-referential use in both English and Kurdish.

१. Some grammarians in English language regard it as a demonstrative reference. Likewise, there are Kurdish grammarians consider third person pronouns as a demonstrative. 


\subsection{Differences:}

1. Demonstratives precede their antecedents in English Language, but in Kurdish their antecedents occur within the demonstratives.

r. The pronominal demonstratives in Kurdish Language occurs as a part, but when it is used as adnominal, they split into two part and the noun they refer to occurs within the demonstrative. However, the demonstratives in English occur as one part in every situation.

$r$. In Kurdish when the demonstrative is used to refer to a determiner and its referent, the determiner and the referent are changed to a compound word and then it occurs within the demonstrative adjective, however, such changes do not occur in English.

๕. Kurdish demonstratives have more than one form, but English have only one form.

○. In Kurdish Language, that (ewe) is used generally and more frequently than (eme) this, but this is used more commonly to refer to antecedents in English.

\section{\&. Conclusion :}

This study indicated that there are more similarities than differences between English and Kurdish demonstratives as expected because they belong to one language family which is Indo European Languages. The usage of the Kurdish and English demonstratives in different contexts are mostly analogous. However, there are vast differences in the form and position between English and Kurdish demonstratives.

\section{•. Implication of the Study}

The findings of the study provide a number of points to reflect on in terms of pedagogical implication. Language teachers can help students to identify the similarities and this leads learners to develop rapidly in learning second language. In addition, instructors can use a method that support the students to avoid (interference) the errors that are affected by their first language.

The discoveries might also give a clear vision between the two languages and this facilitates translation. 


\section{Suggestions for other studies}

Despite the fact that, there are precise investigations on the demonstratives from linguistic aspect, more work is needed to describe the use of the Kurdish demonstratives in different contexts. According to the literature, the choice of both Kurdish and English demonstrative is not decided by the speakers as a result of proximity and distance of the items they refer to only, especially in discourse. There are factors that affect both native speakers and second language speakers in the choice of the demonstratives and they need to be investigated.

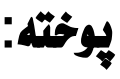

ئهم تويّزينهوهيه بهناوى (لهيهكجو جياوازييهكانى ئامرازهانى نيشـانه له نيّوان زمانى كوردى و

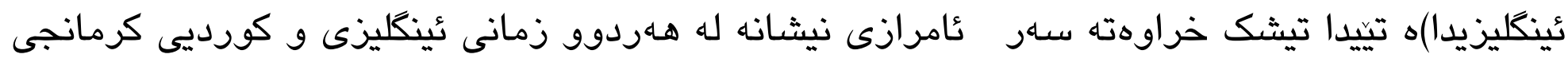

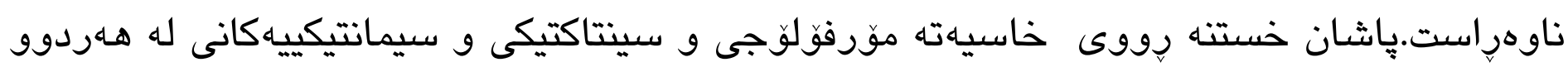

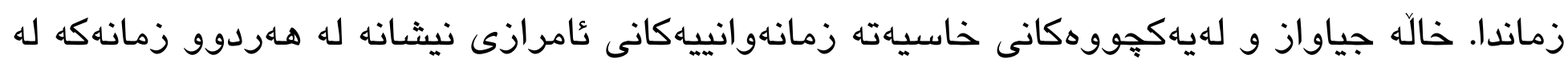

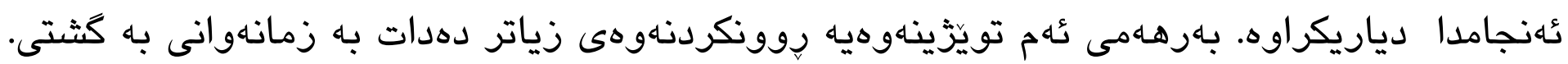

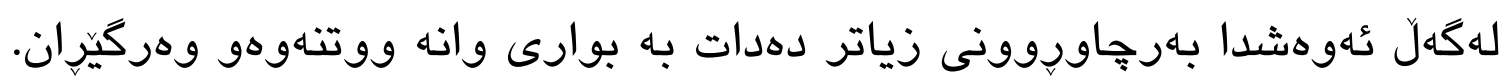

\section{References:}

Arts, B., \& McMhon, A. (2006). The Handbook of English Linguistics. Malden: Blackwell Publishing Ltd.

Crystal, D. (2008). A Dictionary of Linguistics and Phonetics. Malden: Blackwell Publishing.

Diessel, H. (1999). Demonstratives: Form, Function, and Grammaticalization. Amsterdam: John Benjamins.

Endley, M.J. (2010). Linguistic Perspectives on English Grammar. The United States of America: Information Age Publishing.

Fan, c. (2013). Anaphoric Demonstratives and their Antecedents in English Academic Discource. International Journal for English Linguistics, 73-84

Ghubin, B. A. Demonstratives in English and Arabic: A Contrastive Study. Journal of College of Languages, 17-30, Baghdad University. 
Greenbaum, S. (2000). The Oxford Reference Grammar. Oxford: Oxford University Press.

Leech, G., \& Svarvic, j. (2013). A Communicative Grammar of English. NewYork: Routledge.

Maurizio Gotti, M. D. (n.d.) English Historical Linguistics 2006: Syntax and Morphology.

Reppen, R., Gordon, D. (2012). Grammar and Bryond Level 1. Cambridge: Cambridge University Press.

Roberts, C. (1999). Demonstratives as Definites. Conference on Mapping and Semantics. (pp. 89-136). Cornel University: CSLI Publications.

Yoguchi, M. (2001). The Function of Non-deictic that in English. Journal of Pragmatics 1125- 1155.

eurehmanî hacî marf, rêzmanî kurdî, bergî yekem (uşesazî),beşî duwem,cênaw, bexda, 19^v . tara muhsîn qadr, cênaw lêkdaneweyekî nwê le zmanî kurdîda, macstêr, kolêjî zman, zankoy slêmanî, r .. દ. rfîq şwanî, wşesazî zmanî kurdî, çapî yekem, hewlêr, r • 'l. zerê yusupova, şêwey slêmanî zmanî kurdî, w. kurdstan mukryanî, çapî yekem, çapxaney wezaretî perwerde, hewlêr, 2005.

şêrko baban, hendêk le akare rengînekanî rêzmanî kurdî, çapxaney xanî (dhok), çapî yekem, 2005.

mesod mhemed, wrdbûnewe le çend basêkî rêzmanî kurdî, çapxaney korî zanyarî kurd, bexda 1974.

nerîman ebdulla xoşnaw, rêzmanî kurdî krmancî nawerast û krmancî serû, çapî yekem, çapxaney rojhelat, hewlêr, 2012.

nesrîn fexrî, kurdstan mukryanî, rêzmanî kurdî bo polî yekemî beşî zmanî kurdî zankoy selahedîn, 1982.

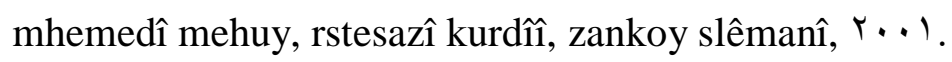

nurî elî emîn, rêzmanî kurdî, çapî sêyem, çapxaney şehab, hewlêr, r• 1 r. 